\title{
Proteomic Profile of Uterine Luminal Fluid from Early Pregnant Ewes
}

\author{
Jill M. Koch ${ }^{\dagger, \ddagger}$, Jayanth Ramadoss ${ }^{\dagger, \ddagger}$, and Ronald R. Magness ${ }^{*}, \neq, \S, \|$ \\ Department of Ob/Gyn Perinatal Research Laboratories, Department of Animal Sciences, and \\ Department of Pediatrics, University of Wisconsin, Madison, Wisconsin
}

\section{Abstract}

Embryonic development is a time-sensitive period that requires a synchronized uterine environment, which is created by the secretion of proteins from both the embryo and uterus. Numerous studies have identified uterine luminal proteins and related these to specific adaptations during early pregnancy (EP). However, no study has yet utilized LC-MS/MS to identify the signature profile of proteins in the uterine lumen during EP. In this study, uterine luminal fluid from nonpregnant (NP; $n=3)$ and $\mathrm{EP}(n=3$; gestational day 16$)$ ewes were analyzed by LC-MS/ MS and validated by Western immunoblotting. We identified a unique signature profile for EP luminal fluid; 15 proteins related to specific aspects of embryonic development including growth and remodeling, immune system regulation, oxidative stress balance, and nutrition were significantly altered (up to 65-fold of NP) in EP profile. Specific uterine remodeling proteins such as transgelin $(P=0.008)$ and placental proteins like PP9 $(P=0.02)$ were present in EP luminal fluid but were barely detectable in the NP flushings. Direct correlations $\left(R^{2}=0.84, P=0.01\right)$ were observed between proteomics and immunoblotting. These data provide information on dynamic physiological processes associated with EP at the level of the uterus and conceptus and may potentially demonstrate a signature profile associated with embryonic well-being.

\section{Keywords}

early pregnancy; uterine luminal fluid; proteomic profile; sheep; embryo; histotroph

\section{Introduction}

Early embryonic development and maternal recognition of pregnancy require a specific well-timed uterine environment. This environment is created in synergy between the developing embryo and the uterus, which inhibits luteolysis, renders the embryo immunologically protected and provides nutrition for the unattached developing embryo. ${ }^{1,2}$ The importance of environment and timing during this period is exemplified by the fact that approximately $30 \%$ of early embryos are lost during this period..$^{3,4}$

\footnotetext{
(C) 2010 American Chemical Society

*Address correspondence: Ronald R. Magness, Ph.D., Perinatal Research Laboratories, Department of Obstetrics and Gynecology, University of Wisconsin-Madison, Atrium B Meriter Hospital, 202 S. Park Street, Madison, WI, 53715, Phone: (608) 417-6314, Fax: (608) 257-1304, rmagness@wisc.edu. .

†qual contribution.

†Department of $\mathrm{Ob} / \mathrm{Gyn}$ Perinatal Research Laboratories.

$\S$ Department of Animal Sciences.

"Department of Pediatrics.
}

Supporting Information Available: The 100 most abundant proteins present in the uterine luminal fluid along with the detailed peptide report. This material is available free of charge via the Internet at http://pubs.acs.org. 
The uterus exerts its own influence on embryonic development through histotrophic nutrition, which is synthesized and secreted by the glandular epithelium and is regulated by both maternal hormones and embryonic secretions. This histotroph contributes to the uterine luminal milieu and consists of enzymes, growth factors, ions, cytokines, hormones, adhesion molecules, nutrients, and transport proteins. ${ }^{5,6}$ The uterine environment during early pregnancy contains at least a 3 -fold increase in nutrients including glucose, amino acids, ions, and electrolytes compared with the nonpregnant state. ${ }^{7,8}$ In addition to uterine secretions, key embryonic secretions are also required for a synchronous interaction between uterine endometrium and embryonic tissues. For example, between days 8 and 16 of gestation the developing conceptus, specifically, the trophectoderm, secretes interferon- $\tau$, which is thought to initiate the process of maternal recognition of pregnancy and is required for proper embryonic development. ${ }^{5,9-11}$ Other studies have identified embryonic proteins including placental protein 9 (PP9), a protein found in the cytoplasm of trophoblast cells and associated with early embryonic attachment. ${ }^{12}$

Despite the vast literature on histotroph proteins and their physiologic importance in attachment, implantation, pregnancy recognition, and luteal maintenance, a limited number of studies have attempted to perform a comprehensive proteomic analysis of uterine luminal fluid. Table 1 provides a list of studies that have so far reported proteomic data in the field of animal reproduction, especially involving some aspect of early pregnancy. Out of these eight reports, only one was performed in sheep, which is the focus of the current manuscript. Specifically, Lee and co-workers ${ }^{12}$ performed large-format $2 \mathrm{D}$ gel electrophoresis and identified placental protein 9 (PP9), actin, and transferrin to be the chief conceptussynthesized proteins in the ovine uterine flushings on gestational day 17 . The majority of the remaining studies were performed in the pig or cow and utilized maternal or placental tissues or fluids including urine, allantoic fluid, and amniotic fluid. However, these studies do not shed light on the uterine milieu during early pregnancy. Further, no study has yet utilized a non-gel-based technique or LC-MS/MS approach to identify the signature profile of proteins in the uterine lumen during early pregnancy in any of the domestic animal species. Identification of the proteomic profile during early pregnancy may not only provide a comprehensive view of the uterine luminal environment during this critical developmental period but also identify potential markers for early pregnancy embryonic losses. It would also provide a window for mechanistic framework of diseases during early pregnancy and potentially give critical information about impending gestational diseases. We therefore utilized LC-MS/MS to identify for the first time a signature profile of proteins in uterine luminal fluid from gestational day 16 compared with the nonpregnant state.

\section{Methods}

\section{Animals and Breeding}

Ewes ( $n=6$ ) of mixed Western breeds were obtained from the University of WisconsinsMadison Arlington farm facility, and all animal protocols were approved by the Research Animal Care and Use Committee of the University of Wisconsin School of Medicine and Public Health, as well as the Colleges of Agriculture and Life Sciences. Estrus was synchronized using a similar protocol to Gibson and co-workers ${ }^{13}$ through the use of progesterone $(0.3 \mathrm{~g})$ impregnated vaginal implants for 10 to 14 days (EAZI-BREED, CIDR, Pfizer, New Zealand). Following the removal of the CIDR, each ewe was administered an intramuscular injection of prostaglandin $\mathrm{F}_{2} \alpha(15 \mathrm{mg}$; Lutalyse, Pfizer; New York, NY) and 500 IU equine chorionic gonadotropin (PMSG; Calbiochem; Darmstadt, Germany). Ewes exhibited estrus (day 0) approximately $48 \mathrm{~h}$ following the last injections. 


\section{Treatment Groups and Uterine Flushing Collection}

Animals were assigned to one of two groups: nonpregnant (NP; $n=3)$ or early pregnant (EP; $n=3$ ) group. EP ewes were bred to a fertile ram at estrus and on day 16 of pregnancy were euthanized for tissue collections. All NP and EP ewes were euthanized (anesthetic dose of sodium pentobarbital followed by bilateral pneumothorax and ventricular laceration) just prior to ovo-hysterectomy, and upon removal of the uterus, uterine horns were flushed separately. In brief, a small incision was made at the base of the uterine horn and a glass cannula with a fluted end was inserted into uterine horn. A blunted needle attached to a syringe was inserted into the oviduct through the infundibulum. The tissue was pinched off around the needle, and $5 \mathrm{~mL}$ of phosphate buffered saline with $0.1 \%$ poly(vinyl alcohol) was flushed through the oviduct and uterine horn to the glass cannula and collected in a Petri dish. Embryos were examined to confirm pregnancy and removed from flushings before each flushing was centrifuged at $3000 \times g\left(10 \mathrm{~min}, 4^{\circ} \mathrm{C}\right)$ to pellet any cellular debri. Flushing solution was then aliquoted and stored at $-80^{\circ} \mathrm{C}$ until further analysis.

\section{Uterine Flushing Peptide Digestion}

Uterine flushing total protein quantification was performed using a modified Lowry assay procedure as described previously. ${ }^{14}$ Following protein assay, flushings were digested as follows. Proteins from $200 \mu \mathrm{L}$ of the flushings were extracted by precipitation with an equal volume of $100 \%$ ice cold acetone, incubated $1 \mathrm{~h}$ on ice, and centrifuged for $10 \mathrm{~min}\left(4{ }^{\circ} \mathrm{C}\right)$ at $16000 \times g$. Pelleted proteins were resolubilized and denatured in $10 \mu \mathrm{L}$ of $6 \mathrm{M}$ urea and 100 $\mathrm{mM} \mathrm{NH}_{4} \mathrm{HCO}_{3}$ for $10 \mathrm{~min}$ and then diluted to $50 \mu \mathrm{L}$ for digestion with $1 \mu \mathrm{L}$ of $25 \mathrm{mM}$ DTT, $7 \mu \mathrm{L}$ of acetonitrile, $22 \mu \mathrm{L}$ of Milli-Q water and $10 \mu \mathrm{L}$ of $20 \mathrm{ng} / \mu \mathrm{L}$ trypsin (Trypsin Gold, PROMEGA Inc.) in $25 \mathrm{mM} \mathrm{NH}_{4} \mathrm{HCO}_{3}$. Following digestion for $2 \mathrm{~h}$ at $42{ }^{\circ} \mathrm{C}, 10 \mu \mathrm{L}$ of trypsin solution was added, and the mixture was incubated at $37{ }^{\circ} \mathrm{C}$ overnight. Reaction was terminated by acidification with $2.5 \%$ trifluoroacetic acid. Peptides generated from digestion were directly loaded for nano-LC-MS/MS analysis.

\section{Proteomic Analysis}

Peptides were analyzed by nano-LC-MS/MS using the Agilent 1100 nanoflow system (Agilent, Palo Alto, CA) connected to a hybrid linear ion trap-orbitrap mass spectrometer (LTQ-Orbitrap, Thermo Fisher Scientific, San Jose, CA) equipped with a nanoelectrospray ion source. As described previously, capillary HPLC was performed using an in-house fabricated column with integrated electrospray emitter essentially ${ }^{15,16}$ except for the usage of a $360 \mu \mathrm{m}$ outer diameter (OD) $\times 75 \mu \mathrm{m}$ inner diameter (ID) fused silica tubing. The column was packed with $5 \mu \mathrm{mC}_{18}$ particles (Column Engineering, Ontario, CA) to approximately $12 \mathrm{~cm}$. Sample loading $(8 \mu \mathrm{L})$ and desalting were achieved using a trapping column in line with the autosampler (Zorbax 300SB-C18, $5 \mu \mathrm{M}, 5 \times 0.3 \mathrm{~mm}^{2}$, Agilent). HPLC solvents were as follows: loading $=1 \%(\mathrm{v} / \mathrm{v}) \mathrm{ACN}, 0.1 \mathrm{M}$ acetic acid; $\mathrm{A}=0.1 \mathrm{M}$ acetic acid in water; $\mathrm{B}=95 \%(\mathrm{v} / \mathrm{v})$ acetonitrile, $0.1 \mathrm{M}$ acetic acid in water. Sample loading and desalting were done at $10 \mu \mathrm{L} / \mathrm{min}$ with the loading solvent delivered from an isocratic pump. Gradient elution was performed at $200 \mathrm{~nL} / \mathrm{min}$ and increasing \%B in $\mathrm{A}$ of 0 to 40 in $200 \mathrm{~min}, 40$ to 60 in $20 \mathrm{~min}$, and 60 to 100 in $5 \mathrm{~min}$. The LTQ- Orbitrap was set to acquire MS/MS spectra in data-dependent mode as follows: MS survey scans from $m / z, 300$ to 2000 were collected in profile mode at a resolving power of 100 000. MS/MS spectra were collected on the five most-abundant signals in each survey scan. Dynamic exclusion was employed to increase dynamic range and maximize peptide identifications. This feature excluded precursors up to $0.55 \mathrm{~m} / \mathrm{z}$ below and $1.05 \mathrm{~m} / \mathrm{z}$ above previously selected precursors. Precursors remained on the exclusion list for $15 \mathrm{~s}$. Singly charged ions and ions for which the charge state could not be assigned were rejected from consideration for MS/ MS. Tandem mass spectra were extracted, charge state deconvoluted, and deisotoped by Bio-Works, version 3.1. Raw MS/MS data were searched against NCBI nonredundant Bos 
taurus amino acid sequence database (Bos_taurus_020209; 64765 entries; for trypsin digestion) using in-house Sequest search engine (ThermoFinnigan, San Jose, CA; version 28 , rev. 13) with a fragment ion mass tolerance of $0.50 \mathrm{Da}$, a parent ion tolerance of $2.5 \mathrm{Da}$, and methionine oxidation as variable modification. ${ }^{17-19}$ We utilized the Bos taurus database because there exists a close morphological-paleontological and immunological phylogentic relationship, as well as a mere $2.92 \pm 0.08 \%$ difference in the gene positions, between the sheep and cow. ${ }^{20,21}$ Scaffold (version 2.06.00; Proteome Software Inc., Portland, OR) was used to validate MS/MS-based peptide and protein identifications. Peptide identifications were accepted if they could be established at a probability of $P<0.05$ as specified by the Peptide Prophet algorithm. ${ }^{22}$ Protein identifications were accepted if they could be established at probability $P<0.05$ and contained at least "two" identified peptides. Protein probabilities were assigned by the Protein Prophet algorithm. ${ }^{23}$ Proteins that contained similar peptides and could not be differentiated based on MS/MS analysis alone were grouped to satisfy the principles of parsimony. An estimate of protein abundance in the sheep uterine luminal fluid was determined by using a normalized spectral count method similar to that described and validated recently by Stevenson and co-workers ${ }^{24}$ and utilized by several reproduction proteomic studies. ${ }^{25-27}$ As described previously, ${ }^{24}$ counted spectra are provided by Scaffold in five different forms: (1) unique peptides, (2) unique spectra, (3) number of identified spectra, (4) percent of total spectra, and (5) unweighted spectral counts. In addition to these, the Scaffold software version 2.06 .00 provides a more sophisticated parameter called quantitative value to estimate protein abundance and is derived from averaging the spectrum counts across biosamples within NP and EP groups, followed by averaging the spectral counts between these two categories, and then multiplying the spectrum counts in each group by the average divided by the individual biosample. We specifically utilized this normalized quantitative value (a score validated by Western blotting in a number of other studies conducted in our laboratory) as a surrogate for the protein abundance. Further, since it has been demonstrated that the relative abundance measurements can be correlated between spectral counts and extracted ion chromatogram signal levels, ${ }^{28}$ we performed further validation by extracting ion chromatograms over a $0.02 \mathrm{amu}$ wide window from the full MS scans.

\section{Immunoblotting}

Post hoc validation of proteomic data was performed using immunoblotting. Fifteen micrograms per biological replicate protein was boiled in SDS sample buffer for $5 \mathrm{~min}$ and electrophoresed on 4-20\% gradient SDS-PAGE gels (Bio-Rad, Hercules, CA) for $100 \mathrm{~min}$ at $150 \mathrm{~V}$. Separated proteins were then electrically $(100 \mathrm{~V}, 30 \mathrm{~min})$ transferred to a PVDF membrane. Nonspecific binding was blocked with 5\% fat-free milk in TBST (50 mm Tris$\mathrm{HCl}, \mathrm{pH} 7.5,0.15 \mathrm{~m} \mathrm{NaCl}, 0.05 \%$ Tween-20) for $120 \mathrm{~min}$ and incubated with primary antibodies $(1 \mu \mathrm{g} / \mathrm{mL} ; 1: 500)$ in TBST $+1 \%$ BSA for $120 \mathrm{~min}$. Antisera specific to transgelin (Abcam, Cambridge, MA), clathrin heavy chain (Cell Signaling Tech. Inc., Cambridge, MA), and $90 \mathrm{kDa}$ Heat shock protein (HSP90; Cell Signaling Tech, Cambridge, MA) were used at dilutions of 1:1000, 1:1000, and 1:1250, respectively. After washing, the membrane was incubated with secondary antibodies (goat antirabbit/HRP conjugate; Amersham Pharmacia Biotech) for transgelin, clathrin heavy chain, and HSP90 at 1:1000, 1:3000, and 1:1000 dilution, respectively, and detected with the Pierce ECL or ECL plus detection kits (Thermo Scientific, Waltham, MA). Levels of protein were then quantified by scanning densitometry (BioRad 670 scanning densitometer).

\section{Statistics}

Proteomic profiling and immunoblotting was performed on uterine luminal fluid from all six ewes, that is, three biological samples per group. After establishment of normality and equal variance, difference in the mean protein abundance factor between NP and EP groups was 
analyzed using Student's $t$ test. $\alpha$ level of significance was established $a$ priori at $P<0.05$. EP profile (Mean \pm SEM) was expressed as fold change from NP.

\section{Results}

The 100 most abundant proteins present in the uterine luminal fluid along with the detailed peptide report is shown in Supporting Information. Gene Ontology terms are not listed for any of the proteins in the uterine luminal fluid. Therefore, we manually categorized these proteins based on their role in early pregnancy. This categorization included every protein including those that were not altered by gestation (Figure 1). We observed that $38 \%$ of the proteome was associated with growth and remodeling, $30 \%$ with nutrition, $22 \%$ with immune system, and 5\% with oxidative stress. In addition, $5 \%$ of the proteins were classified as miscellaneous because they had no known function listed in the NCBI protein database or were proven to be of blood origin (e.g., hemoglobin $\alpha$ and $\beta$ ). We conducted additional validation to confirm that hemoglobin $\alpha$ and $\beta$ were of maternal blood origin and were not secreted by the uterus or the embryo by performing additional proteomic analyses on blood, uterine flushing and blood, and uterine flushing samples (data not shown).

Out of the 100 most abundant uterine luminal proteins, we identified 15 proteins to be significantly altered in the EP state (Figure 2). Among those directly related to the immune system, three proteins of which two belonged to the complement component (CC) family were altered; CC5 $(P=0.016)$, immunoglobulin heavy constant mu (IGHM; $P=0.041)$, and $\mathrm{CC} 4 \mathrm{~A}(P=0.002)$ were significantly elevated in the EP group. Four proteins related to nutrition were significantly altered in EP uterine luminal fluid; adenosylhomocysteinase $(P$ $=0.042$ ), glucose 6 phosphate isomerase (GPI; $P=0.039$ ), and apolipoprotein AI (APO-AI; $P=0.014)$ were elevated, whereas ceruloplasmin was decreased $(P=0.002)$ in the EP group. Of the uterine luminal proteins relating to oxidative stress balance, only paraoxonase was significantly increased $(P=0.025)$ in EP profile. A number of proteins related to growth and remodeling were significantly elevated in the EP uterine luminal profile including $\alpha 1 \mathrm{~B}$ glycoprotein (A1BG; $P=0.033$ ), actinin 4 (ACTN4; $P=0.040$ ), BCL2-like 15 (BCL2-L15; $P=0.034)$, carbonic anhydrase II (CA II; $P=0.047)$, transgelin $(P=0.008)$, PP9 $(P=$ $0.0212)$, and $\alpha 2$ macroglobulin (A2M; $P=0.003)$.

Proteomics data was validated using immunoblotting (Figure 3). Among the 15 proteins that were significantly altered in the EP profile, only one antibody (anti-transgelin) with a good homology for sheep or cow was available. We also probed for heavy chain clathrin and HSP90 as representatives of uterine luminal proteins that were not altered in the EP proteomic profile. Similar to the proteomics data, Western blotting demonstrated that transgelin (optical density, $0.651 \pm 0.066)$ was found in significantly greater abundance $(P<$ $0.01)$ in the EP group compared with the NP group. Similarly, no statistical difference was observed in the protein abundance of either heavy chain clathrin $(P=0.754)$ or HSP90 $(P=$ 0.602 ) between groups providing further validation of the proteomics data.

For further validation, we specifically chose the protein transgelin because the proteomics and Western data demonstrated that this protein was abundantly present in the EP uterine luminal fluid and barely detectable in the NP profile. We then analyzed extracted ion chromatograms for the protein transgelin (Figure 4A). Out of the three NP samples, no peptides were identified in the uterine luminal fluid sample from one ewe, whereas in the remaining two samples one peptide was identified in each. In contrast, 8, 12, and 15 peptides were identified in the three EP uterine luminal fluid samples, respectively. A representative extracted ion chromatogram of the transgelin peptide (HVIGLQMGSNR) over a $0.02 \mathrm{amu}$ wide window illustrated that the relative abundance measurements were consistent among normalized spectral counting method, Western blotting, and extracted ion chromatogram 
signal levels. Further, the transgelin abundance scores calculated by utilizing the normalized spectral counting method correlated significantly $\left(R^{2}=0.84 ; P=0.01\right)$ with the Western blotting optical density measures (Figure 4B).

\section{Discussion}

This is the first study to utilize a non-gel-based LC-MS/MS technique to illustrate the signature profile of uterine luminal fluid in early pregnancy among any domestic animal species. In the current study, we observed that both NP and EP uterine luminal fluid consisted of proteins related to growth and remodeling, immune system, oxidative stress, and nutrition. Of the 100 most abundant proteins in the ovine uterine luminal fluid, 15 specific proteins were significantly altered in the EP profile; specific proteins like transgelin and PP9 were barely detectable in the uterine luminal fluid collected from NP sheep whereas they were present in great abundance in the EP profile. These data provide considerable evidence for the discovery of a novel signature pattern(s) of the early pregnancy uterine environment. Furthermore, the period of initial attachment is a critical phase during the establishment of pregnancy, and in some species, including humans, information about the coordinated sequence and steps that lead to successful attachment is limited. ${ }^{29}$ Therefore, the specific signature profile in this study may provide information on the physiological processes associated with early pregnancy at the level of the uterus and the conceptus and may serve as an indicator of embryo well-being.

During early pregnancy, the ovine uterine wall undergoes active growth and structural remodeling to support embryonic development. ${ }^{30}$ Therefore, it is not surprising that six of the 15 proteins that were differentially expressed in the EP profile in this study were related to growth and remodeling. These included A1BG, ACTN4, BCL2-L15, CA II, transgelin, PP9, and A2M. A1BG, a glycoprotein that has been reported to be substantially expressed in bovine conceptus fluids, ${ }^{31}$ was abundant in EP uterine luminal fluid. Consistent with previous reports that ACTN4 is expressed during porcine trophoblastic elongation and early attachment to the uterine endometrium, ${ }^{32}$ we also observed significant increases in ACTN4 in the EP luminal profile. BCL2-L15 was increased significantly in the EP uterine luminal fluid. Although little is known about the function of BCL2-L15, we listed this protein under the category of growth and considered it to be a BCL family protein. An increase in CA II in the EP profile was not surprising because CA II mRNA is expressed in the endometrial luminal epithelium and has been suggested to play a role in endometrial gland development and uterine morphogenesis. ${ }^{33}$ Transgelin, a $22 \mathrm{kDa}$ protein constitutively expressed in the uterus $^{34}$ and previously described as a biomarker for arterial vessel remodeling in uterine tissue $^{34}$ and as a protein associated with endometriosis ${ }^{35}$ was elevated in the EP profile in the present study. The EP luminal fluid also contained a substantial abundance of PP9, a trophoblast protein, ${ }^{36}$ which was barely detectable in the NP profile. This result is in agreement with previous reports that PP9 is found in great abundance in uterine luminal fluid from early pregnant ewes (gestational day 17). ${ }^{12} \mathrm{PP} 9$ catalyzes the conversion of glucose to fructose, which may be significant at this point of development because fructose is the primary sugar in fetal fluids. ${ }^{12,37}$ Similar to the suggestion by Lee and co-workers, ${ }^{12}$ our data also indicates that the switch to fructose begins during early embryonic development because PP9 was extremely abundant on gestational day 16. A2M is a protease inhibitor produced by the endometrial stroma and is widely suggested to play a significant role in regulating preimplantation embryo development and endometrial remodeling. ${ }^{38,39}$ Finally, these data provide evidence at the proteomic level for remodeling of the uterus during the preimplantation period in order to accommodate the rapidly developing conceptus. 
We observed that three proteins related to the immune system including two belonging to the complement component family were significantly elevated in the EP uterine luminal fluid profile. The complement component system is an immunity defense system that plays a role in both embryonic and host protection. ${ }^{40,41}$ This study also provides additional information for determining a potential function for the protein paraoxonase in early pregnancy. Consistent, with our observation, it has been previously reported that paraoxonase is elevated in the serum of pregnant women. ${ }^{42}$ Since antioxidant(s) administration is negatively correlated with oxidative stress and the pathogenesis of preeclampsia, a pregnancy associated disease phenotype, ${ }^{43,44}$ our data on the presence of oxidative stress-balance associated proteins in the EP profile may also provide information for future studies on the origins of preeclampsia at the embryonic development stage.

Among the 15 proteins that were altered in the EP profile, four were associated with nutrition. We observed that adenosylhomocysteinase, the enzyme that regulates the production of homocysteine, an amino acid widely associated with many obstetric diseases including spontaneous miscarriages, intrauterine growth restriction, and preeclampsia, was significantly elevated in the EP treatment group. ${ }^{45,46} \mathrm{GPI}$, a protein associated with glucose metabolism and closely linked with early implantation, ${ }^{47}$ was also elevated in the EP group. Furthermore, APO-AI was significantly increased in the EP uterine luminal fluid. In humans, plasma APO-AI levels are increased during pregnancy and their levels decrease only with parturition. ${ }^{48-50}$ Moreover, maternal plasma APO-AI levels are reduced in preeclampsia compared with those in normal pregnancy. ${ }^{50,51}$ The only protein that was decreased in the EP uterine luminal profile was ceruloplasmin, a protein found in the uterine epithelial cells of rats, and consistent with our findings it has been reported that its mRNA levels decrease during the preimplantation phase of early pregnancy, before increasing at the time of implantation. ${ }^{52}$

Specific proteins found in the current uterine flushing proteome have been previously well characterized in other animal ${ }^{31,12}$ and human ${ }^{53,54}$ reproductive tissues and conceptusderived fluids. Consistent with our findings, it has been previously demonstrated using 2D gel analysis that serum albumin, APO-AI, transferrin, and PP9 are among the most abundant proteins in the ovine uterine luminal fluid on gestational day $17 .{ }^{12}$ These proteins are also detected in high abundance in bovine allantoic fluid later in gestation (gestational day 45). ${ }^{31}$ As documented by Lee and co-workers, ${ }^{12}$ other specific proteins that have been previously well studied in uterine luminal fluid include proteins belonging to serpin family, ${ }^{55}$ retinol binding protein, ${ }^{56}$ kunitz-type proteinases ${ }^{57}$ and interferon $\tau .{ }^{58}$ Out of these proteins, serpin family proteins and retinol binding protein were indeed detected in high abundance in the currently reported flushings, whereas kunitz-type proteinases and interferon- $\tau$ were detected in relatively lower abundance in the EP uterine luminal fluid but, as expected, were absent in the NP luminal fluid. It should also be noted that the presence of serum proteins like albumin in the uterine lumen is also consistent with several previous reports. ${ }^{12,59}$

The current data also demonstrate that the proteomics abundance scores calculated by utilizing the Scaffold's (version 2.06.00) normalized spectral counting method is a reliable measure of protein abundance. Data in Figure 3 demonstrated that no differences were found between the proteomic protein abundance score and the Western blotting optical density measure. A significant correlation was noted between the measurements made by both of these techniques (Figure 4B). A recent report has also validated several measures calculated by Scaffold as excellent estimates of protein abundance and as an alternative to label-based and gel-based techniques. ${ }^{24}$ Finally, we also validated these results using the extracted ion chromatograms and the relative abundance measurements were consistent with the normalized spectral counting method, Western blotting, and the ion chromatogram signal levels. 
In conclusion, we have utilized LC-MS/MS to illustrate a distinctive proteomic signature uterine luminal fluid profile for early ovine pregnancy. This proteomic profile during early pregnancy provides a comprehensive view of the uterine luminal environment during this critical developmental period. These data suggest that this profile may consist of markers that may identify pregnancy-associated disease phenotypes whose origins begin in early pregnancy (e.g., preeclampsia). The categorization of the proteins in the EP uterine luminal profile also provides a window for evaluating the mechanistic framework of the physiological state of the uterus during this stage of ovine gestation.

\section{Supplementary Material}

Refer to Web version on PubMed Central for supplementary material.

\section{Acknowledgments}

The authors thank Terrance Phernetton, Kreg Grindle, Gladys Lopez, Sheikh Jobe, Timothy Morschauser, and Jason Austin for their assistance with animal preparation and sample collection, Cindy Goss for her assistance with the bibliography, and Grzegorz Sabat and Greg Barrett-Wilt at the Biotech Center at University of WisconsinMadison for their assistance with mass spectrometry. This work was funded by Grants NIH HL49210, HD38843, and HL87144.

\section{References}

(1). Ashworth CJ, Bazer FW. Changes in ovine conceptus and endometrial function following asynchronous embryo transfer or administration of progesterone. Biol. Reprod. 1989; 40(2):42533. [PubMed: 2720035]

(2). Roberts RM. Conceptus interferons and maternal recognition of pregnancy. Biol. Reprod. 1989; 40(3):449-52. [PubMed: 2667647]

(3). Bolet, G. Timing and extent of embryonic mortality in pigs, sheep and goats: Genetic variability. In: Sreenan, JM., editor. Embryonic Mortality in Farm Animals. Vol. 34. M. Nijhoff; Dordrecht, the Nether-lands: 1986. p. 12-43.Current topics in veterinary medicine and animal science

(4). Dixon AB, Knights M, Winkler JL, Marsh DJ, Pate JL, Wilson ME, Dailey RA, Seidel G, Inskeep EK. Patterns of late embryonic and fetal mortality and association with several factors in sheep. J. Anim. Sci. 2007; 85(5):1274-84. [PubMed: 17224462]

(5). Spencer TE, Johnson GA, Bazer FW, Burghardt RC. Implantation mechanisms: Insights from the sheep. Reproduction. 2004; 128(6):657-68. [PubMed: 15579583]

(6). Igwebuike UM. Trophoblast cells of ruminant placentas--A minireview. Anim. Reprod. Sci. 2006; 93(3-4):185-98. [PubMed: 16043315]

(7). Gao H, Wu G, Spencer TE, Johnson GA, Li X, Bazer FW. Select nutrients in the ovine uterine lumen. I. Amino acids, glucose, and ions in uterine lumenal flushings of cyclic and pregnant ewes. Biol. Reprod. 2009; 80(1):86-93. [PubMed: 18753605]

(8). Gao H, Wu G, Spencer TE, Johnson GA, Bazer FW. Select nutrients in the ovine uterine lumen. II. Glucose transporters in the uterus and peri-implantation conceptuses. Biol. Reprod. 2009; 80(1): 94-104. [PubMed: 18753604]

(9). Godkin JD, Bazer FW, Moffatt J, Sessions F, Roberts RM. Purification and properties of a major, low molecular weight protein released by the trophoblast of sheep blastocysts at day 13-21. J. Reprod. Fertil. 1982; 65(1):141-50. [PubMed: 7077590]

(10). Roberts RM. A novel group of interferons associated with the early ovine and bovine embryo. J. Interferon Res. 1989; 9(4):373-8. [PubMed: 2666529]

(11). Spencer TE, Johnson GA, Burghardt RC, Bazer FW. Progesterone and placental hormone actions on the uterus: Insights from domestic animals. Biol. Reprod. 2004; 71(1):2-10. [PubMed: 14973264]

(12). Lee RS, Wheeler TT, Peterson AJ. Large-format, two-dimensional polyacrylamide gel electrophoresis of ovine periim-plantation uterine luminal fluid proteins: Identification of aldose 
reductase, cytoplasmic actin, and transferrin as conceptus-synthesized proteins. Biol. Reprod. 1998; 59(4):743-52. [PubMed: 9746721]

(13). Gibson TC, Phernetton TM, Wiltbank MC, Magness RR. Development and use of an ovarian synchronization model to study the effects of endogenous estrogen and nitric oxide on uterine blood flow during ovarian cycles in sheep. Biol. Reprod. 2004; 70(6):1886-94. [PubMed: 14985241]

(14). Magness RR, Shaw CE, Phernetton TM, Zheng J, Bird IM. Endothelial vasodilator production by uterine and systemic arteries. II. Pregnancy effects on NO synthase expression. Am. J. Physiol. 1997; 272(4 Pt 2):H1730-40. [PubMed: 9139957]

(15). Martin SE, Shabanowitz J, Hunt DF, Marto JA. Subfemtomole MS and MS/MS peptide sequence analysis using nano-HPLC micro-ESI fourier transform ion cyclotron resonance mass spectrometry. Anal. Chem. 2000; 72(18):4266-74. [PubMed: 11008759]

(16). Ramadoss J, Liao WX, Chen DB, Magness RR. High-throughput caveolar proteomic signature profile for maternal binge alcohol consumption. Alcohol. 2010 DOI: 10.1016/j.alcohol. 2009.10.010.

(17). Vanden Wymelenberg A, Gaskell J, Mozuch M, Sabat G, Ralph J, Skyba O, Mansfield SD, Blanchette RA, Martinez D, Grigoriev I, Kersten PJ, Cullen D. Comparative transcriptome and secretome analysis of wood decay fungi Postia placenta and Phanerochaete chrysosporium. Appl. Environ. Microbiol. 2010; 76(11):3599-610. [PubMed: 20400566]

(18). Sun S, Meyer-Arendt K, Eichelberger B, Brown R, Yen CY, Old WM, Pierce K, Cios KJ, Ahn NG, Resing KA. Improved validation of peptide MS/MS assignments using spectral intensity prediction. Mol. Cell. Proteomics. 2007; 6(1):1-17. [PubMed: 17018520]

(19). Wang J, Perez-Santiago J, Katz JE, Mallick P, Bandeira N. Peptide identification from mixture tandem mass spectra. Mol. Cell. Proteomics. 2010; 9:1476-85. [PubMed: 20348588]

(20). Lowenstein JM. Molecular phylogenetics. Annu. Rev. Earth Planet Sci. 1986; 14:71-83.

(21). Kijas JW, Menzies M, Ingham A. Sequence diversity and rates of molecular evolution between sheep and cattle genes. Anim. Genet. 2006; 37(2):171-4. [PubMed: 16573533]

(22). Keller A, Nesvizhskii AI, Kolker E, Aebersold R. Empirical statistical model to estimate the accuracy of peptide identifications made by MS/MS and database search. Anal. Chem. 2002; 74(20):5383-92. [PubMed: 12403597]

(23). Nesvizhskii AI, Keller A, Kolker E, Aebersold R. A statistical model for identifying proteins by tandem mass spectrometry. Anal. Chem. 2003; 75(17):4646-58. [PubMed: 14632076]

(24). Stevenson SE, Chu Y, Ozias-Akins P, Thelen JJ. Validation of gel-free, label-free quantitative proteomics approaches: applications for seed allergen profiling. J. Proteomics. 2009; 72(3):55566. [PubMed: 19049836]

(25). Dasari S, Pereira L, Reddy AP, Michaels JE, Lu X, Jacob T, Thomas A, Rodland M, Roberts CT Jr. Gravett MG, Nagalla SR. Comprehensive proteomic analysis of human cervical-vaginal fluid. J. Proteome Res. 2007; 6(4):1258-68. [PubMed: 17373839]

(26). Michaels JE, Dasari S, Pereira L, Reddy AP, Lapidus JA, Lu X, Jacob T, Thomas A, Rodland M, Roberts CT Jr. Gravett MG, Nagalla SR. Comprehensive proteomic analysis of the human amniotic fluid proteome: gestational age-dependent changes. J. Proteome Res. 2007; 6(4):127785. [PubMed: 17373841]

(27). Pereira L, Reddy AP, Jacob T, Thomas A, Schneider KA, Dasari S, Lapidus JA, Lu X, Rodland M, Roberts CT Jr. Gravett MG, Nagalla SR. Identification of novel protein biomarkers of preterm birth in human cervical-vaginal fluid. J. Proteome Res. 2007; 6(4):1269-76. [PubMed: 17373840]

(28). Zybailov B, Coleman MK, Florens L, Washburn MP. Correlation of relative abundance ratios derived from peptide ion chromatograms and spectrum counting for quantitative proteomic analysis using stable isotope labeling. Anal. Chem. 2005; 77(19):6218-24. [PubMed: 16194081]

(29). Hearn JP. The embryo-maternal dialogue during early pregnancy in primates. J. Reprod. Fertil. 1986; 76(2):809-19. [PubMed: 3517317]

(30). Igwebuike UM. A review of uterine structural modifications that influence conceptus implantation and development in sheep and goats. Anim. Reprod. Sci. 2009; 112(1-2):1-7. [PubMed: 19162416] 
(31). Riding GA, Jones A, Holland MK, Hill JR, Lehnert SA. Proteomic analysis of bovine conceptus fluids during early pregnancy. Proteomics. 2008; 8(1):160-77. [PubMed: 18095355]

(32). Ross JW, Ashworth MD, Stein DR, Couture OP, Tuggle CK, Geisert RD. Identification of differential gene expression during porcine conceptus rapid trophoblastic elongation and attachment to uterine luminal epithelium. Physiol. Genomics. 2009; 36(3):140-8. [PubMed: 19033546]

(33). Hu J, Spencer TE. Carbonic anhydrase regulate endometrial gland development in the neonatal uterus. Biol. Reprod. 2005; 73(1):131-8. [PubMed: 15788756]

(34). Camoretti-Mercado B, Forsythe SM, LeBeau MM, Espinosa R 3rd, Vieira JE, Halayko AJ, Willadsen S, Kurtz B, Ober C, Evans GA, Thweatt R, Shapiro S, Niu Q, Qin Y, Padrid PA, Solway J. Expression and cytogenetic localization of the human SM22 gene (TAGLN). Genomics. 1998; 49(3):452-7. [PubMed: 9615232]

(35). Kyama CM, T'Jampens D, Mihalyi A, Simsa P, Debrock S, Waelkens E, Landuyt B, Meuleman C, Fulop V, Mwenda JM, D'Hooghe TM. ProteinChip technology is a useful method in the pathogenesis and diagnosis of endometriosis: a preliminary study. Fertil. Steril. 2006; 86(1):2039. [PubMed: 16716317]

(36). Inaba N, Renk T, Bohn H. Immunohistochemical location of placental proteins (PP 8, 9, 10, 11 12) in human term placentae. Arch. Gynecol. 1980; 230(2):109-21. [PubMed: 7458419]

(37). Huggett AS, Nixon DA. Fructose as a component of the foetal blood in several mammalian species. Nature. 1961; 190:1209. [PubMed: 13716607]

(38). Sayegh R, Awwad JT, Maxwell C, Lessey B, Isaacson K. Alpha 2-macroglobulin production by the human endometrium. J. Clin. Endocrinol. Metab. 1995; 80(3):1021-6. [PubMed: 7533769]

(39). Sayegh RA, Tao XJ, Leykin L, Isaacson KB. Endometrial alpha-2 macroglobulin; localization by in situ hybridization and effect on mouse embryo development in vitro. J. Clin. Endocrinol. Metab. 1997; 82(12):4189-95. [PubMed: 9398738]

(40). Fishelson Z, Attali G, Mevorach D. Complement and apoptosis. Mol. Immunol. 2001; 38(2-3): 207-19. [PubMed: 11532282]

(41). Girardi G, Bulla R, Salmon JE, Tedesco F. The complement system in the pathophysiology of pregnancy. Mol. Immunol. 2006; 43(1-2):68-77. [PubMed: 16023727]

(42). Roy AC, Loke DF, Saha N, Viegas OA, Tay JS, Ratnam SS. Interrelationships of serum paraoxonase, serum lipids and apolipoproteins in normal pregnancy. A longitudinal study. Gynecol. Obstet. Invest. 1994; 38(1):10-3. [PubMed: 7959317]

(43). Chappell LC, Seed PT, Briley AL, Kelly FJ, Lee R, Hunt BJ, Parmar K, Bewley SJ, Shennan $\mathrm{AH}$, Steer PJ, Poston L. Effect of antioxidants on the occurrence of pre-eclampsia in women at increased risk: A randomised trial. Lancet. 1999; 354(9181):810-6. [PubMed: 10485722]

(44). Roberts JM, Cooper DW. Pathogenesis and genetics of preeclampsia. Lancet. 2001; 357(9249): 53-6. [PubMed: 11197372]

(45). Palmer JL, Abeles RH. The mechanism of action of S-adenosylhomocysteinase. J. Biol. Chem. 1979; 254(4):1217-26. [PubMed: 762125]

(46). de la Calle M, Usandizaga R, Sancha M, Magdaleno F, Herranz A, Cabrillo E. Homocysteine, folic acid and B-group vitamins in obstetrics and gynaecology. Eur. J. Obstet. Gynecol. Reprod. Biol. 2003; 107(2):125-34. [PubMed: 12648856]

(47). Schulz LC, Bahr JM. Glucose-6-phosphate isomerase is necessary for embryo implantation in the domestic ferret. Proc. Natl. Acad. Sci. U.S.A. 2003; 100(14):8561-6. [PubMed: 12826606]

(48). Silliman K, Tall AR, Kretchmer N, Forte TM. Unusual high-density lipoprotein subclass distribution during late pregnancy. Metabolism. 1993; 42(12):1592-9. [PubMed: 8246775]

(49). Del Priore G, Chatterton RT Jr. Chandarana A, Silver R. Comparison of maternal serum lipids before and during parturition. Obstet. Gynecol. 1993; 82(5):837-40. [PubMed: 8414334]

(50). Ndikum-Moffor FM, Simmen RC, Fields PA, Katoh N, Oikawa S, Buhi WC, Rollyson MK, Chang SM, Fields MJ. Synthesis and messenger ribonucleic acid expression of apolipo-proteins E and A-I by the bovine corpus luteum during the estrous cycle and pregnancy. Biol. Reprod. 1997; 56(3):745-56. [PubMed: 9047021] 
(51). Rosing U, Samsioe G, Olund A, Johansson B, Kallner A. Serum levels of apolipoprotein, A.-I. A-II and HDL-cholesterol in second half of normal pregnancy and in pregnancy complicated by pre-eclampsia. Horm. Metab. Res. 1989; 21(7):376-82. [PubMed: 2506119]

(52). Thomas T, Macpherson A, Rogers P. Ceruloplasmin gene expression in the rat uterus. Biochim. Biophys. Acta. 1995; 1261(1):77-82. [PubMed: 7893763]

(53). Shaw JL, Smith CR, Diamandis EP. Proteomic analysis of human cervico-vaginal fluid. J. Proteome Res. 2007; 6(7):2859-65. [PubMed: 17567164]

(54). Casado-Vela J, Rodriguez-Suarez E, Iloro I, Ametzazurra A, Alkorta N, Garcia-Velasco JA, Matorras R, Prieto B, Gonzalez S, Nagore D, Simon L, Elortza F. Comprehensive proteomic analysis of human endometrial fluid aspirate. J. Proteome Res. 2009; 8(10):4622-32. [PubMed: 19670903]

(55). Ing NH, Roberts RM. The major progesterone-modulated proteins secreted into the sheep uterus are members of the serpin superfamily of serine protease inhibitors. J. Biol. Chem. 1989; 264(6): 3372-9. [PubMed: 2464597]

(56). Clawitter J, Trout WE, Burke MG, Araghi S, Roberts RM. A novel family of progesteroneinduced, retinol-binding proteins from uterine secretions of the pig. J. Biol. Chem. 1990; 265(6): 3248-55. [PubMed: 2303448]

(57). Stallings-Mann ML, Burke MG, Trout WE, Roberts RM. Purification, characterization, and cDNA cloning of a Kunitz-type proteinase inhibitor secreted by the porcine uterus. J. Biol. Chem. 1994; 269(39):24090-4. [PubMed: 7929061]

(58). Imakawa K, Anthony RV, Kazemi M, Marotti KR, Polites HG, Roberts RM. Interferon-like sequence of ovine trophoblast protein secreted by embryonic trophectoderm. Nature. 1987; 330(6146):377-9. [PubMed: 2446135]

(59). Kayser JP, Kim JG, Cerny RL, Vallet JL. Global characterization of porcine intrauterine proteins during early pregnancy. Reproduction. 2006; 131(2):379-88. [PubMed: 16452731]

(60). Chae JI, Cho SK, Seo JW, Yoon TS, Lee KS, Kim JH, Lee KK, Han YM, Yu K. Proteomic analysis of the extraembryonic tissue from cloned porcine embryos. Mol. Cell. Proteomics. 2006; 5(9):1559-66. [PubMed: 16815948]

(61). Pyo J, Hwang SI, Oh J, Lee SJ, Kang SC, Kim JS, Lim J. Characterization of a bovine pregnancy-associated protein using two-dimensional gel electrophoresis, N-terminal sequencing and mass spectrometry. Proteomics. 2003; 3(12):2420-7. [PubMed: 14673792]

(62). Berendt FJ, Frohlich T, Schmidt SE, Reichenbach HD, Wolf E, Arnold GJ. Holistic differential analysis of embryo-induced alterations in the proteome of bovine endometrium in the preattachment period. Proteomics. 2005; 5(10):2551-60. [PubMed: 15912510]

(63). Kim HR, Kang JK, Yoon JT, Seong HH, Jung JK, Lee HM, Sik Park C, Jin DI. Protein profiles of bovine placenta derived from somatic cell nuclear transfer. Proteomics. 2005; 5(16):4264-73. [PubMed: 16196098]

(64). Daikoku T, Tranguch S, Friedman DB, Das SK, Smith DF, Dey SK. Proteomic analysis identifies immunophilin FK506 binding protein 4 (FKBP52) as a downstream target of Hoxa10 in the periimplantation mouse uterus. Mol. Endocrinol. 2005; 19(3):683-97. [PubMed: 15528267] 


\section{Most Abudant Proteins in Uterine Flushings}

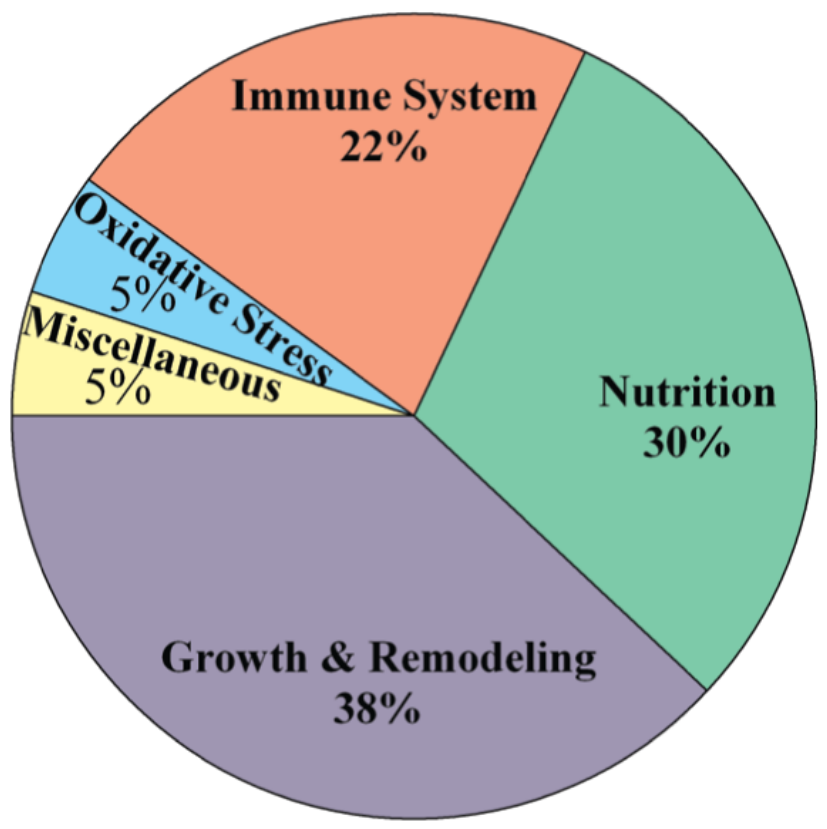

Figure 1.

Categorization of the 100 most abundant proteins in early pregnant (EP) ovine uterine luminal fluid measured by LC MS/MS. The categorizations shown included every protein even those that were not altered by gestation. Specifically $38 \%$ of the proteome was associated with growth and remodeling, 30\% with nutrition, $22 \%$ with immune system, and $5 \%$ with oxidative stress, whereas $5 \%$ of the proteins were classified as miscellaneous because they had no known function listed in the NCBI protein database or were of blood origin (e.g., hemoglobin $\alpha$ and $\beta$ ). 


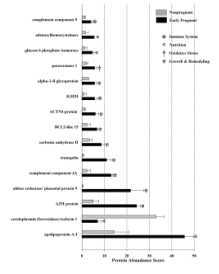

Figure 2.

Nonpregnant (NP) and early pregnant (EP) ovine uterine luminal fluid proteomic profile. Among the 100 most abundant and identifiable proteins, 15 proteins were significantly altered in the EP profile compared with the NP. Please refer to "Results" for abbreviations. Significantly altered proteins are symbol-coded based on their role in early pregnancy. Proteins are listed from most abundant (bottom) to least abundant (top), and data are expressed as mean \pm SEM. 


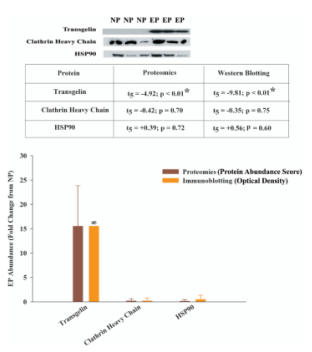

Figure 3.

Immunoblot validation of proteomic data. Similar to the proteomic data, Western blotting demonstrated that transgelin $(P<0.01)$ was found in significantly higher abundance $(*)$ in the early pregnant (EP) group compared with the nonpregnant (NP) ovine uterine luminal fluid. Further, no difference was observed in the protein abundance of either heavy chain clathrin $(P=0.75)$ or HSP90 $(P=0.60)$ between groups. Data are expressed as mean \pm SEM. 

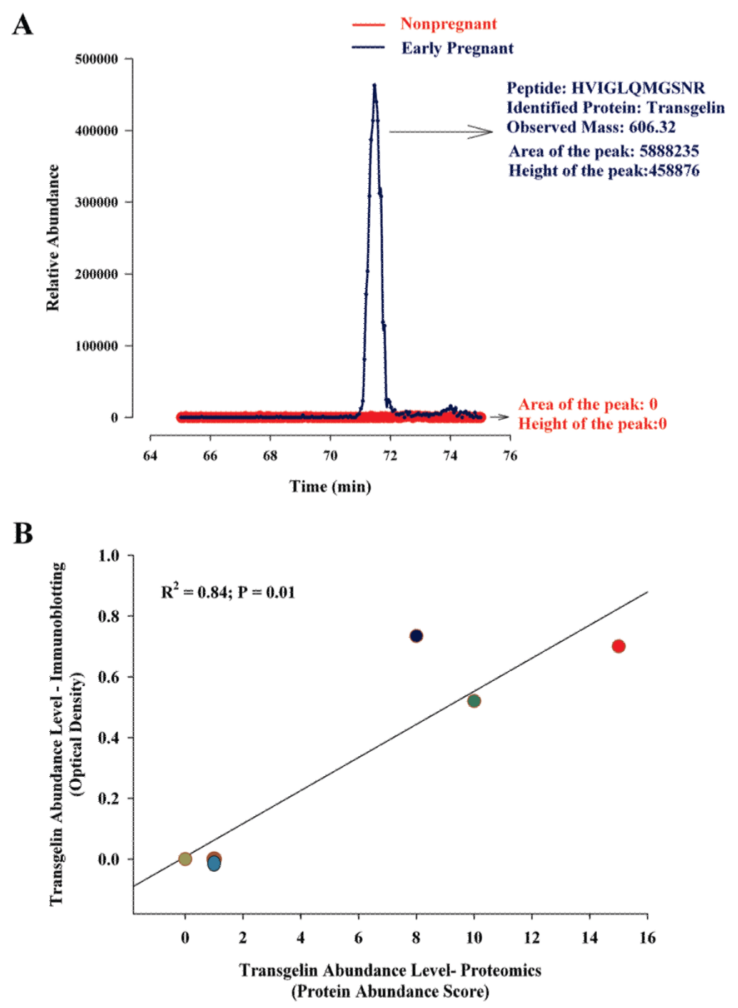

Figure 4.

(A) Representative extracted ion chromatogram of the transgelin peptide (HVIGLQMGSNR) over a 0.02 amu wide window illustrated that the relative abundance measurements were consistent among normalized spectral counting method, Western blotting, and extracted ion chromatogram signal levels. (B) Protein abundance scores calculated by utilizing the normalized spectral counting method correlated significantly for transgelin $\left(R^{2}=0.84 ; P=0.01\right)$ with the Western blotting optical density measures. 
